\title{
Influence of Nipping and Hormonal Sprays on Growth and Seed Yield in Field Bean [Lablab purpureus (L.) Sweet] Genotypes
}

\author{
E. Sudeep Kumar ${ }^{1 *}$, A. S. Channaveerswami ${ }^{1}$, M. N. Merwade ${ }^{1}$, V. Rudra Naik ${ }^{2}$ and A. Krishna ${ }^{1}$
}

${ }^{1}$ Dept. of Seed Science and Technology, ${ }^{2}$ Dept. of Genetics and Plant Breeding, University of Agricultural Sciences, Dharwad

(580 005), India

\section{Corresponding Author}

E. Sudeep Kumar

e-mail: 41.sudi@gmail.com

\author{
Article History \\ Article ID: IJEP0222 \\ Received in $26^{\text {th }}$ October, 2017 \\ Received in revised form $1^{\text {st }}$ February, 2018 \\ Accepted in final form $10^{\text {th }}$ February, 2018
}

\begin{abstract}
A field experiment was conducted to know the influence of nipping and hormonal sprays on growth and seed yield of field bean genotypes at the Main Agricultural Research Station, University of Agricultural Sciences, Dharwad. The treatments include two genotypes (G : $_{1} \mathrm{DA}_{-8}$, $\mathrm{G}_{2}$ : $\mathrm{HA}-3$ ), two nipping operations ( $\mathrm{N}_{1}$ : No nipping, $\mathrm{N}_{2}$ : Nipping), hormonal sprays $\left(\mathrm{S}_{1}\right.$ : Water spray as control, $\mathrm{S}_{2}: \mathrm{GA}_{3} @ 50$ ppm and $\mathrm{S}_{3}: \mathrm{MH}$ @ $50 \mathrm{ppm}$ ) and their interactions. Genotype HA-3 recorded higher number of branches (13.27), dry matter (266.34 g plant $\left.{ }^{-1}\right)$ and seed yield (1966 kg ha-1) at harvest as compared to genotype DA-8 Nipping of plants at 55 DAS lead to decrease in plant height but increased the number of branches (14.20), dry matter (283.02 $\mathrm{g} \mathrm{plant}^{-1}$ ) and seed yield ( $\left.2166 \mathrm{~kg} \mathrm{ha}^{-1}\right)$. Among hormonal sprays, plants sprayed with $\mathrm{GA}_{3}$ recorded higher plant height $(136.77 \mathrm{~cm})$ while, the other growth parameters recorded were higher with $\mathrm{MH}$ application and also registered higher seed yield (1953 $\left.\mathrm{kg} \mathrm{ha}^{-1}\right)$. The interaction effect between G ' N, G ' S, N ' S and G ' N ' S were non significant for majority of the characters studied. However, in both the genotypes nipped plants sprayed with $\mathrm{MH}$ recorded higher growth and yield parameters compared to either $\mathrm{GA}_{3}$ or water sprays and also with no nipping.
\end{abstract}

Keywords: Field bean, genotypes $(\mathrm{G})$, gibberellic acid $\left(\mathrm{GA}_{3}\right)$, maleic hydrazide $(\mathrm{MH})$, nipping $(\mathrm{N})$, seed yield

\section{Introduction}

Lablab purpureus L. Sweet is an important legume crop cultivated in the tropical regions of Asia, Africa and America. It is mainly cultivated either as a pure crop or mixed with finger millet, groundnut, castor, corn, bajra or sorghum in Asia and Africa. It is a multipurpose crop grown for pulse, vegetable and forage. In the diet of southern states of India, it is one of the major sources of protein. Lablab is remarkably adaptable to wide areas under diverse climatic conditions such as arid, semi-arid, sub-tropical and humid regions where temperature vary between $22^{\circ} \mathrm{C}$ to $35^{\circ} \mathrm{C}$, low-lands and uplands and many types of soils and the $\mathrm{pH}$ varying from 4.4 to 7.8 . Being a legume, it can fix atmospheric nitrogen to the extent of 170 $\mathrm{kg} \mathrm{ha}^{-1}$ besides leaving enough crop residues to enrich the soils with organic matter. It is a drought tolerant crop and grows well in dry lands with limited rainfall. The crop prefers relatively cool seasons with temperature ranging from $14{ }^{\circ} \mathrm{C}$ to $28^{\circ} \mathrm{C}$. Non availability of quality seeds, absence of suitable seed production technology, heavy incidence of pest and diseases, inadequate post harvest handling operations and lack of knowledge about the varieties by the farmers lead to fall in productivity of field bean varieties. Among these constraints, the average productivity could be enhanced by developing suitable low cost seed production technology by combining conventional and scientific practices for achieving the commercial success of the crop.

Among several seed production approaches, apical bud nipping (pinching) is being commonly practiced in several crops to increase the seed yield and quality. Nipping of young tender top shoots though traditionally practiced by the farmer but its associated beneficial effects are not scientifically documented. Among the various cultural practices, apical bud pinching (nipping) is one which is practiced to enhance flower bearing branches by curbing vegetative growth which ultimately reflects on the seed yield and quality of crop (Vasudevan et al., 2008). Beneficial effects noticed with pinching perhaps could be related to effective synthesis and translocation of photosynthates from source to sink which is evident with higher seed weight (Baloch and Zubair, 2010, Olfati and Malakouti, 2013; Krishnaveni et al., 2014). Apical bud pinching helps in production of side shoots or branches thus resulting in increased photosynthetic activity and accumulation of more photosynthates ultimately resulting in increased seed size and yield (Lakshmi et al., 2015). The studies on influence of nipping on seed yield and quality in field bean varieties are absolutely very scanty. 
A plant hormone is an organic substance other than a nutrient, active in very minute amounts, which is formed in certain parts of the plant and usually transported to other sites, where it evokes specific biochemical, physiological and morphological responses. Growth hormones like $\mathrm{GA}_{3}$ and Maleic hydrazide $(\mathrm{MH})$ are known to regulate the plant growth in many crops. They play an important role in regulating the physiological process and balancing the source-sink relationship thereby increase in productivity and quality of resultant crop (Lakshmi et al., 2015). Maleic hydrazide (MH) is an inhibitor which arrests apical dominance and induces lateral buds to grow. It causes reduction in stem length which is attributed to a reduction in cell division, cell enlargement, alters osmotic solutes in the cell, restricts permeability of water, imbalances wall pressure and wall synthesis. The increased in number and yield of flowers might be due to increased in number of branches and also removal of apical dominance due to $\mathrm{MH}$ which ultimately enhanced the flower production (Navale et al., 2010). Gibberellic acid application brings metabolic changes that affect both quality and quantity of the desired product. It stimulates synthesis of hydrolytic enzymes which are secreted and act on starchy endosperm in turn affecting physiology of seed germination and establishment of seedlings. Gibberellic acid $\left(\mathrm{GA}_{3}\right)$ has been used to increase the length or height of plants, increase the number of flowers and induce flowering (Medina and Saavedra, 2005).

Nipping and hormonal sprays are known to influence the plant characteristics in several ways. The interaction effect of growth regulator (plant hormones) with pinching had a positive influence on yield attributing characters in marigold (Badge et al., 2015). Keeping above constraints in mind, the studies were undertaken to find out the influence of nipping and hormonal sprays on growth and seed yield parametres in field bean genotypes.

\section{Materials and Methods}

A field experiment was conducted to study the influence of nipping and hormonal spray on growth and seed yield parameters in field bean genotypes during kharif, 2009 at Main Agricultural Research Station, University of Agricultural Sciences, Dharwad. The experiment consisted of 12 treatment combinations involving two genotypes ( $G_{1}$ : $D A-8$ and $\left.G_{2}: H A-3\right)$, two levels of nipping ( $\mathrm{N}_{1}$ : no nipping and $\mathrm{N}_{2}$ : nipping) at 55 DAS and three foliar hormonal sprays $(S)$ viz., $S_{1}$ : water spray (control), $\mathrm{S}_{2}: \mathrm{GA}_{3}(50 \mathrm{ppm}), \mathrm{S}_{3}: \mathrm{MH}(50 \mathrm{ppm})$ and experiment was laid out in Randomized block design with factorial concept in three replications with spacing of $60 \times 45 \mathrm{~cm}^{2}$.

\section{Results and Discussion}

\subsection{Influence of genotypes (G)}

Significant variation in plant height at harvest was observed in field bean genotypes irrespective of nipping and hormonal sprays. In general, DA-8 $\left(\mathrm{G}_{1}\right)$ genotype recorded more plant height $(142.40 \mathrm{~cm})$ at harvest. Ironically, the number of branches (13.27) and number of leaves (53.9) were maximum in HA-3 $\left(G_{2}\right)$ genotype at the time of harvest (Table 1.), compared to DA-8 $\left(G_{1}\right)$ and such genotypic differences in number of branches and number of leaves were also reported by Merwade (2000); Bulla (2009) in chickpea.

The days to flower initiation and $50 \%$ flowering is genetically controlled and influenced by the environment prevailing during crop growth period. HA-3 $\left(G_{2}\right)$ genotype took significantly less (52.96) days to initiate flowering and also for days to $50 \%$ flowering (65.85) compared to $D A-8\left(G_{1}\right)$ genotype, which took more days (Table 2 ). Similar reports of genotypic variations on days to $50 \%$ flowering were made in chickpea by Merwade (2000) and Bulla (2009).

Between the genotypes, HA-3 $\left(G_{2}\right)$ genotype recorded significantly more dry matter (266.34 g plant $\left.^{-1}\right)$, number of pods plant ${ }^{-1}(114.58)$ and pod weight plant ${ }^{-1}(144.76$ g) except for pod length (Table 3). Similarly, number of seeds pod ${ }^{-1}$ (4.75), seed yield plant ${ }^{-1}$ (122.53 g) and seed yield (1966 kg $\left.\mathrm{ha}^{-1}\right)$ was more in $\mathrm{HA}-3\left(\mathrm{G}_{2}\right)$ genotype (Table 4$)$. The differences on seed yield and yield parameters observed between the genotypes in the present study may be attributed to their differences in growth habit and genetic yielding ability. Similar genotypic differences in chickpea with respect to plant growth have been reported by Merwade (2000) and Bulla (2009) in chickpea and on seed yield and yield attributes by Reddy (2005) in cowpea.

\subsection{Influence of nipping $(N)$}

Between nipping and no nipping treatments, non-nipped $\left(\mathrm{N}_{1}\right)$ plants recorded significantly more plant height at harvest $(136.87 \mathrm{~cm})$ compared to nipped plants $\left(\mathrm{N}_{2}\right)$. While, nipped plants $\left(\mathrm{N}_{2}\right)$ recorded significantly higher number of branches (14.20), number of leaves (56.6) at harvest compared to nonnipped plants (Table 1).

The higher plant height noticed with no nipping $\left(\mathrm{N}_{1}\right)$ treatment was mainly due to the fact that plants were not nipped and as such plants grew to their original height without reduction. While, number of branches plant ${ }^{-1}$ were more in case of nipped plants. This may be due to nipping effect of apical buds which resulted in production of more secondary branches and restriction to vertical growth on account of effective translocation of hormones, particularly auxins which are being diverted to the potential and tertiary shoot buds which in normal conditions remain dormant. According to Singh and Singh (1992) reasons for the above change was that the energy which was provisionally used by the plant was diverted towards branching. Similar reports were made by Shankargoud and Patil (1994) in sunflower, Sharma et al. (2003) in pigeonpea, Khan et al. (2006) in chickpea and Singh and Devi (2006) in pea.

Between nipping treatments, though days to flower initiation was non significant but the nipping treatment took more days (78.37 days) to $50 \%$ flowering and recorded higher dry matter plant $^{-1}$ at harvest (283.02 g) compared to non nipped plants 
Table 1: Effect of nipping and hormonal spray on plant height, no. of branches and number of leaves at harvest in field bean genotypes

\begin{tabular}{|c|c|c|c|c|c|c|c|c|c|c|c|c|c|}
\hline \multicolumn{2}{|c|}{ Treatments } & \multicolumn{4}{|c|}{ Plant height $(\mathrm{cm})$} & \multirow{2}{*}{\multicolumn{4}{|c|}{ No. of branches }} & \multicolumn{4}{|c|}{ No. of leaves } \\
\hline & & \multicolumn{3}{|c|}{ GxNxS } & \multirow[b]{2}{*}{ GxN } & & & & & \multicolumn{3}{|c|}{ GxNxS } & \multirow[b]{2}{*}{ GxN } \\
\hline & & $\mathrm{S}_{1}$ & $\mathrm{~S}_{2}$ & $\mathrm{~S}_{3}$ & & $\mathrm{~S}_{1}$ & $\mathrm{~S}_{2}$ & $\mathrm{~S}_{3}$ & GxN & $\mathrm{S}_{1}$ & $\mathrm{~S}_{2}$ & $\mathrm{~S}_{3}$ & \\
\hline \multirow[t]{2}{*}{ G1 } & $\mathrm{N}_{1}$ & 148.20 & 161.60 & 140.60 & 150.13 & 10.20 & 9.80 & 10.64 & 10.21 & 44.1 & 40.5 & 47.3 & 44.0 \\
\hline & $\mathrm{N}_{2}$ & 135.40 & 139.88 & 128.70 & 134.66 & 13.74 & 12.00 & 13.89 & 13.21 & 54.1 & 52.6 & 54.6 & 53.8 \\
\hline \multirow[t]{2}{*}{ G2 } & $\mathrm{N}_{1}$ & 123.30 & 124.50 & 123.00 & 123.60 & 11.41 & 10.99 & 11.67 & 11.36 & 48.0 & 47.8 & 49.5 & 48.4 \\
\hline & $\mathrm{N}_{2}$ & 115.08 & 121.10 & 114.36 & 116.85 & 14.67 & 14.09 & 16.80 & 15.19 & 58.1 & 58.0 & 62.2 & 59.4 \\
\hline \multirow[t]{2}{*}{$\mathrm{G} \times \mathrm{S}$} & $\mathrm{G}_{1}$ & 141.80 & 150.74 & 134.65 & 142.40 & 11.97 & 10.90 & 12.27 & 11.71 & 49.1 & 46.6 & 50.9 & 48.9 \\
\hline & $\mathrm{G}_{2}$ & 119.19 & 122.80 & 118.68 & 120.22 & 13.04 & 12.54 & 14.24 & 13.27 & 53.0 & 52.9 & 55.8 & 53.9 \\
\hline \multirow[t]{3}{*}{$N \times S$} & $N_{1}$ & 135.75 & 143.05 & 131.80 & 136.87 & 10.81 & 10.39 & 11.16 & 10.78 & 46.1 & 44.2 & 48.4 & 46.2 \\
\hline & $\mathrm{N}_{2}$ & 125.24 & 130.49 & 121.53 & 125.75 & 14.21 & 13.04 & 15.35 & 14.20 & 56.1 & 55.3 & 58.4 & 56.6 \\
\hline & Mean & 130.50 & 136.77 & 126.67 & 131.31 & 12.51 & 11.72 & 13.25 & 12.49 & 51.1 & 49.7 & 53.4 & 51.4 \\
\hline \multicolumn{3}{|c|}{$\begin{array}{l}\text { For comparison means } \\
\text { of }\end{array}$} & SEm \pm & $\begin{array}{c}C D \\
(p=0.05)\end{array}$ & & & S.Em \pm & $\begin{array}{c}C D \\
(p=0.05)\end{array}$ & & & S.Em \pm & $\begin{array}{c}C D \\
(p=0.05)\end{array}$ & \\
\hline \multicolumn{3}{|c|}{ Genotypes (G) } & 0.416 & 1.220 & & & 0.30 & 0.87 & & & 0.89 & 2.62 & \\
\hline \multicolumn{3}{|c|}{ Nipping(N) } & 0.416 & 1.220 & & & 0.30 & 0.87 & & & 0.89 & 2.62 & \\
\hline \multicolumn{3}{|c|}{ Sprays (S) } & 0.509 & 1.494 & & & 0.36 & 1.07 & & & 1.09 & NS & \\
\hline \multicolumn{3}{|c|}{ GxN } & 0.588 & 1.725 & & & 0.42 & NS & & & 1.26 & NS & \\
\hline \multicolumn{3}{|l|}{ GXS } & 0.720 & 2.112 & & & 0.51 & NS & & & 1.55 & NS & \\
\hline \multicolumn{3}{|l|}{ NxS } & 0.720 & NS & & & 0.51 & NS & & & 1.55 & NS & \\
\hline \multicolumn{3}{|c|}{ GxNxS } & 1.019 & 2.987 & & & 0.73 & NS & & & 2.19 & NS & \\
\hline
\end{tabular}

NS: Non Significant; Genotypes (G): G1- DA-8; $G_{2}-H A-3$; Nipping (N): $\mathrm{N}_{1}-$ No nipping; $\mathrm{N}_{2}$ - Nipping; Hormonal sprays (S) : $\mathrm{S}_{1}$ : Water spray (Control); $\mathrm{S}_{2}: \mathrm{GA} 3(50 \mathrm{ppm}) ; \mathrm{S}_{3}-\mathrm{MH}$ (50 ppm)

(76.42 days and $213.18 \mathrm{~g} \mathrm{plant}^{-1}$, respectively) (Table 2 ). The delay in flowering in nipped plants may be due to the fact that nipping of apical buds temporarily hinders the multiplication of meristematic cells in the growing tip. The results are in conformity with Gujar and Srivatsava (1972); Sajjan et al. (2002) in okra; Sudarshan (2004) in fenugreek.

The plants nipped $\left(\mathrm{N}_{2}\right)$ at 55 days after sowing (DAS) recorded significantly highest values for all the seed yield parameters. The number of pods plant ${ }^{-1}(120.02)$, pod length $(5.31 \mathrm{~cm})$, pod weight plant ${ }^{-1}(156.20 \mathrm{~g})$ (Table 3), seeds pod ${ }^{-1}(4.87)$, seed yield plant ${ }^{-1}(134.98 \mathrm{~g})$ and $\mathrm{ha}^{-1}(2166 \mathrm{~kg})$ (Table 4) were more with nipping treatment. This increase in seed yield and yield attributing parameters noticed with nipping was attributed to production of more number of productive branches in chickpea by Khan et al. (2006). According to Singh and Singh (1992) and Singh and Devi (2006) nipping is known to accumulate more photosynthates which are utilized for production of more number of pods bearing branches and more number of seeds pod ${ }^{-1}$ in pea. Similarly, Khan et al. (2006) opined that although the correlation between number of branches and seed yield is always positive and their magnitude has been increased considerably in chickpea with nipping. Similar increase in seed yield and yield parameters with nipping were also reported by Sharma et al. (2003) in pigeonpea and Reddy (2005) in cowpea.

\subsection{Influence of hormonal spray $(H)$}

The plant height at harvest was significantly higher in $\mathrm{GA}_{3}(50$ $\mathrm{ppm})\left(\mathrm{S}_{2}\right)$ and was least in $\mathrm{MH}(50 \mathrm{ppm})\left(\mathrm{S}_{3}\right)$. The plant height at harvest was markedly maximum $(136.77 \mathrm{~cm}$ ) (Table 1$)$, took less ( 66.44 days) to flower initiation and (75.95 days) to $50 \%$ flowering with $\mathrm{GA}_{3} 50 \mathrm{ppm}$ spray (Table 2). This is due to hormonal action of enhancing cell elongation. Further, $\mathrm{GA}_{3}$ acts at the gene level influencing the translation and transcription mechanisms of protein biosynthesis (Key, 1969), hus resulting in early flowering compared to $\mathrm{MH}\left(\mathrm{S}_{3}\right)$ and control $\left(\mathrm{S}_{1}\right)$. Similar results were obtained in okra by Shrivastava and Sachan (1971). On the contrary, at harvest significantly higher values for number of branches (13.25), number of leaves (53.4) (Table 1) and dry matter production at harvest $\left(260.67 \mathrm{~g}\right.$ plant $\left.^{-1}\right)$ were recorded with $\mathrm{MH}$ spray over $\mathrm{GA}_{3}$ and control (Table 2). These findings are similar to the findings of Chauhan and Singh (1972) in capsicum. The apical growth is antagonized by $\mathrm{MH}$, which might have helped to increase accumulation of metabolites and diverted towards the axillary buds in 
Table 2: Effect of nipping and hormonal spray on days to flower initiation, days to $50 \%$ flowering and dry matter production in field bean genotypes

\begin{tabular}{|c|c|c|c|c|c|c|c|c|c|c|c|c|c|}
\hline & \multirow{2}{*}{\multicolumn{4}{|c|}{$\begin{array}{c}\text { Days to flower initiation } \\
\text { GxNxS }\end{array}$}} & \multicolumn{4}{|c|}{ Days to $50 \%$ flowering } & \multicolumn{4}{|c|}{ Dry matter at harvest (g plant ${ }^{-1}$ ) } \\
\hline \multicolumn{2}{|c|}{ Treatments } & & & & & \multicolumn{3}{|c|}{ GxNxS } & \multicolumn{5}{|c|}{ GxNxS } \\
\hline & & $\mathrm{S}_{1}$ & $\mathrm{~S}_{2}$ & $\mathrm{~S}_{3}$ & GxN & $\mathrm{S}_{1}$ & $\mathrm{~S}_{2}$ & $\mathrm{~S}_{3}$ & GxN & $\mathrm{S}_{1}$ & $\mathrm{~S}_{2}$ & $\mathrm{~S}_{3}$ & GxN \\
\hline \multirow[t]{2}{*}{$\mathrm{G}_{1}$} & $\mathrm{~N}_{1}$ & 81.67 & 79.67 & 80.42 & 80.58 & 88.00 & 86.42 & 89.00 & 87.81 & 199.57 & 193.68 & 202.64 & 198.63 \\
\hline & $\mathrm{N}_{2}$ & 82.38 & 81.51 & 81.69 & 81.86 & 90.00 & 89.18 & 91.00 & 90.06 & 260.15 & 246.52 & 276.56 & 261.08 \\
\hline \multirow[t]{2}{*}{$\mathrm{G}_{2}$} & $\mathrm{~N}_{1}$ & 52.50 & 51.19 & 52.00 & 51.90 & 65.53 & 62.19 & 67.35 & 65.02 & 223.67 & 218.13 & 241.40 & 227.73 \\
\hline & $\mathrm{N}_{2}$ & 54.00 & 53.39 & 53.91 & 53.77 & 67.00 & 66.00 & 67.03 & 66.68 & 311.06 & 281.71 & 322.10 & 304.96 \\
\hline \multirow[t]{2}{*}{ GxS } & $\mathrm{G}_{1}$ & 82.02 & 80.59 & 81.06 & 81.22 & 89.00 & 87.80 & 90.00 & 88.93 & 229.86 & 220.10 & 239.60 & 229.85 \\
\hline & $\mathrm{G}_{2}$ & 53.25 & 52.29 & 52.96 & 52.83 & 66.27 & 64.10 & 67.19 & 65.85 & 267.37 & 249.92 & 281.75 & 266.34 \\
\hline \multirow[t]{2}{*}{ NxS } & $\mathrm{N}_{1}$ & 67.08 & 65.43 & 66.21 & 66.24 & 76.77 & 74.31 & 78.18 & 76.42 & 211.62 & 205.91 & 222.02 & 213.18 \\
\hline & $\mathrm{N}_{2}$ & 68.19 & 67.45 & 67.80 & 67.81 & 78.50 & 77.59 & 79.01 & 78.37 & 285.61 & 264.12 & 299.33 & 283.02 \\
\hline \multicolumn{2}{|c|}{ Mean } & 67.64 & 66.44 & 67.01 & 67.03 & 77.63 & 75.95 & 78.59 & 77.39 & 248.61 & 235.01 & 260.67 & 248.10 \\
\hline \multicolumn{3}{|c|}{$\begin{array}{l}\text { For comparison } \\
\text { means of }\end{array}$} & SEm \pm & $\begin{array}{c}C D \\
(p=0.05)\end{array}$ & & & SEm \pm & $\begin{array}{c}\mathrm{CD} \\
(p=0.05)\end{array}$ & & & SEm \pm & $\begin{array}{c}C D \\
(p=0.05)\end{array}$ & \\
\hline \multicolumn{3}{|c|}{ Genotypes (G) } & 0.58 & 1.70 & & & 0.46 & 1.35 & & & 3.63 & 10.64 & \\
\hline \multicolumn{3}{|c|}{ Nipping (N) } & 0.58 & NS & & & 0.46 & 1.35 & & & 3.63 & 10.64 & \\
\hline \multicolumn{3}{|c|}{ Sprays (S) } & 0.71 & NS & & & 0.56 & 1.65 & & & 4.44 & 13.03 & \\
\hline \multicolumn{3}{|l|}{ GxN } & 0.82 & NS & & & 0.65 & NS & & & 5.13 & NS & \\
\hline \multicolumn{3}{|l|}{ GxS } & 1.00 & NS & & & 0.80 & NS & & & 6.28 & NS & \\
\hline \multicolumn{3}{|l|}{ NxS } & 1.00 & NS & & & 0.80 & NS & & & 6.28 & NS & \\
\hline \multicolumn{3}{|c|}{ GxNxS } & 1.42 & NS & & & 1.12 & NS & & & 8.89 & NS & \\
\hline
\end{tabular}

NS: Non significant; Genotypes (G): $G_{1}-D A-8 ; G_{2}-H A-3$; Nipping (N): $N_{1}-$ No nipping; $N_{2}$ : Nipping; Hormonal sprays (S): $S_{1}$ : Water spray (Control); $\mathrm{S}_{2}: \mathrm{GA}_{3}(50 \mathrm{ppm}) ; \mathrm{S}_{3}: \mathrm{MH}(50 \mathrm{ppm})$

the production of more number of branches and leaves and there by increased the spread of plants. These results are in conformity with those of Singh and Sarkar (1976) in soybean and of Vilas (1985) in cowpea.

The foliar spray of hormones showed significant differences on seed yield and yield attributes. The number of pods plant ${ }^{-1}$ (120.02) and pod weight plant ${ }^{-1}(156.20 \mathrm{~g})$ (Table 3), seed yield plant $^{-1}(121.69 \mathrm{~g})$ and ha-1 $(1953 \mathrm{~kg}$ ) (Table 4) were significantly more with MH spray over other treatments. Pod length and number of seeds pod $^{-1}$ did not exhibit any significant difference among hormonal spray. The significant increase in seed yield and yield attributes obtained with the spray of hormones may be attributed to more number of productive branches plant ${ }^{-1}$, leaves plant ${ }^{-1}$ and pods plant ${ }^{-1}$. Further, growth regulators influence carbon cycle in plant with higher $\mathrm{CO}_{2}$ fixation and efficient translocation of synthates towards developing seed (Menon and Srivastava, 1984; Tripathi, et al., 2001) in chickpea. The similar higher seed yield obtained is attributed to altering of dry matter distribution in the plant or by regulating growth (Cathey, 1964).

\subsection{Interaction of genotypes and nipping $(G \times N)$}

The plant height at harvest differed significantly but numbers of branches and number of leaves were found to be non significant due to interaction effect of genotypes and nipping. The plant height at harvest was maximum $(150.13 \mathrm{~cm})$ in DA-8 genotype in no nipping treatment whereas, nipped plants showed lesser plant height in both the genotypes (Table 1). Similarly increase in number of branches due to nipping treatments were also reported by lyyannagouda, (2003) in coriander, Sajjan and Jamadar (2003) in bhendi and Sudarshan (2004) in fenugreek and was related to production of auxin, which in turn stimulates buds sprouting. Likewise, days to flower initiation, $50 \%$ flowering and dry matter production did not show any significant variation due to interactions of genotypes and nipping.

The nipping treatment within field bean genotypes namely HA-3 and DA- 8 has resulted in production of higher number of pods plant ${ }^{-1}(136.21$ and 115.23$)$, pod weight plant ${ }^{-1}$ (173.19 $\mathrm{g}$ and $139.22 \mathrm{~g}$ ), pod length $(5.46 \mathrm{~cm}$ and $5.17 \mathrm{~cm}$ ) (Table $3)$, seeds pod ${ }^{-1}$ (5.06 and 4.67), seed yield plant ${ }^{-1}$ (144.22 g and $125.73 \mathrm{~g}$ ) and $\mathrm{ha}^{-1}(2315 \mathrm{~kg}$ and $2018 \mathrm{~kg})$ respectively over respective no nipping treatments (Table 4). Although, nipping treatment in both the genotypes has not shown any significant influence on any of seed yield parameters 
Table 3: Effect of nipping and hormonal spray on no. of pods, pod weight plant ${ }^{-1}$ and pod length in field bean genotypes

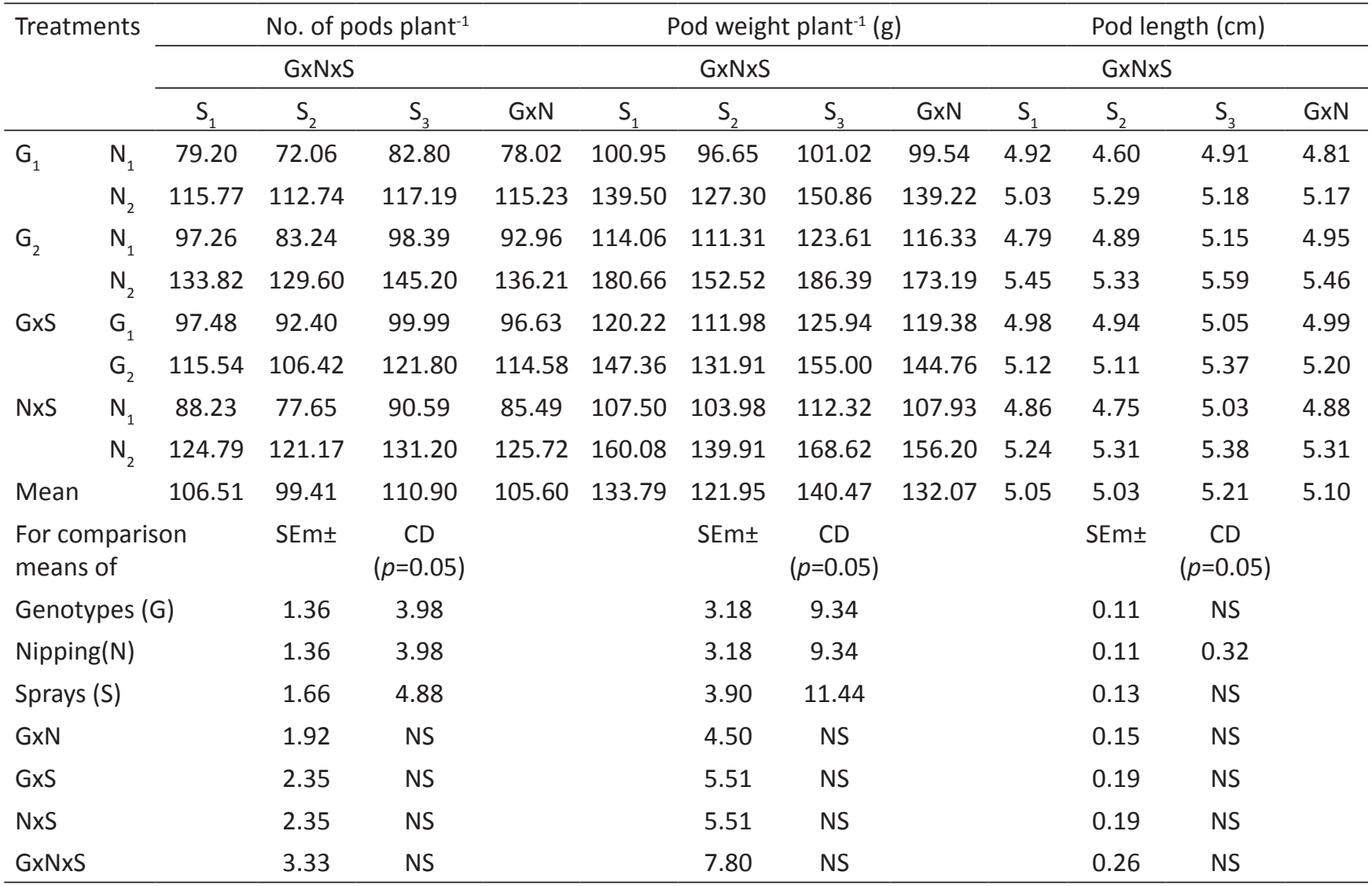

NS: Non Significant; Genotypes (G): $G_{1}-D A-8 ; G_{2}-H A-3$; Nipping (N): $N_{1}-$ No nipping; $N_{2}-$ Nipping; Hormonal sprays $(S): S_{1}$ : Water spray (Control); $\mathrm{S}_{2}: \mathrm{GA}_{3}(50 \mathrm{ppm}) ; \mathrm{S}_{3}-\mathrm{MH}$ (50 ppm)

and yield, the nipping in field bean was found beneficial to enhance these yield traits. Similar increase in seed yield traits and yield were reported by Shankargoud and Patil (1994) in sunflower, Sharma et al. (2003) in pigeonpea and Khan et al. (2006) in chickpea.

\subsection{Interaction of genotypes and hormonal spray $(G \times S)$}

Foliar spray of GA 50 ppm in DA-8 and HA-3 recorded relatively more plant height $(90.09 \mathrm{~cm}$ and $58.38 \mathrm{~cm})$ and number of branches (14.24 and 10.90) (Table 1) respectively at harvest compared to $\mathrm{MH}$ spray. This marginal increase observed in these two growth parameters in the present study may be related to poor genotypic responses for foliar sprays of growth regulators owing to limited genetic potential of the genotypes. Likewise, days to flower initiation, $50 \%$ flowering and dry matter production was not influenced by foliar spray of hormones in both field bean genotypes which is also a genetic trait of these genotypes.

In the present study, the combination effect of genotype and hormonal spray (GXS) was found to be non significant on yield and yield attributes. However, pods plant ${ }^{-1}$ (121.80), pod weight (155.0 g), pod length (5.37) (Table 3 ), seeds pod ${ }^{-1}$ (4.92), seed yield plant ${ }^{-1}(129.84 \mathrm{~g})$ and ha- ${ }^{-1}(2083.86 \mathrm{~kg})$ were numerically more in genotype $\mathrm{HA}-3$ sprayed with $\mathrm{MH}\left(\mathrm{G}_{2} \mathrm{~S}_{3}\right)$
(Table 4). The final seed yield ha-1 ${ }^{-1}$ was maximum (2084 kg and $1822 \mathrm{~kg}$ ) in both the field bean genotypes sprayed with $\mathrm{MH}$ $50 \mathrm{ppm}$ compared to either $\mathrm{GA}_{3}$ or water spray treatments. Similar increase in yield was reported by Reddy (2005) in vegetable cowpea and was attributed to more number of productive branches, leaf thickness, number of pods plant ${ }^{-1}$, number of seeds pod ${ }^{-1}$ and total dry matter. These findings are also supported by the results obtained by Sharma et al. (2003) in pigeonpea.

\subsection{Interaction of nipping and hormonal spray $(N \times S)$}

In the present investigation, plant height, number of branches, number of leaves, days to flower initiation, days to $50 \%$ flowering and dry matter production at various stages were not influenced by the combined effect of nipping and foliar sprays. However, the plant height was relatively more at all the stages of growth in non-nipped plants with all the hormonal sprays compared to control as expected, while number of branches were more at harvest in nipped plants with all the foliar sprays of the growth regulators which was also expected with these treatments, since nipping results in arresting vertical growth and stimulates shoot axillary buds. The results are in accordance with the earlier reports made by lyyannagouda (2003) in coriander and Reddy (2005) in cowpea. 
Table 4: Effect of nipping and hormonal spray on number of seeds pod ${ }^{-1}$, seed yield plant ${ }^{-1}$ and seed yield ha ${ }^{-1}$ in field bean genotypes

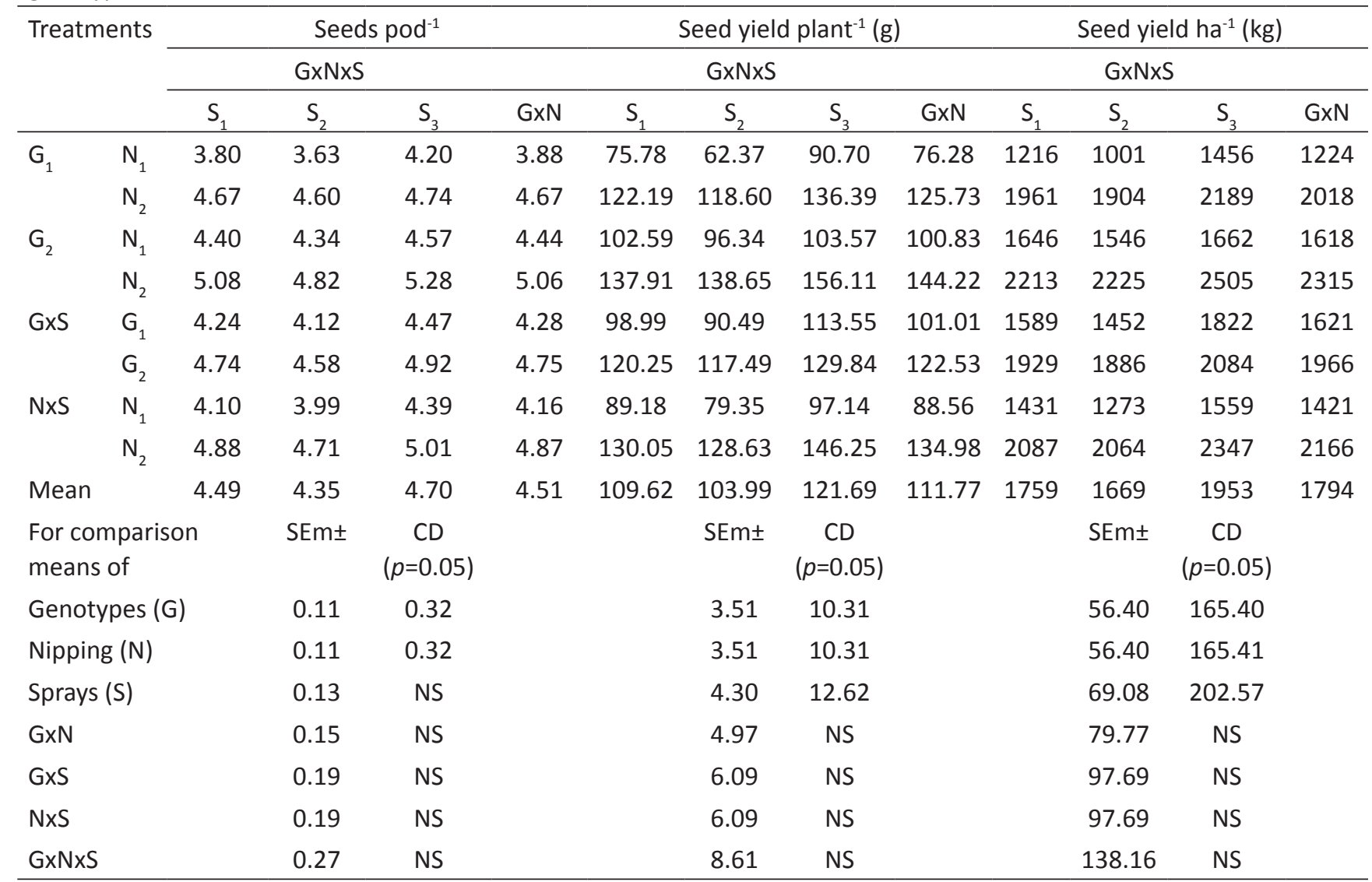

NS: Non Significant; Genotypes (G): $G_{1}-D A-8 ; G_{2}-H A-3$; Nipping (N): $N_{1}-$ No nipping; $N_{2}-$ Nipping; Hormonal sprays (S): $S_{1}$ : Water spray (Control); $\mathrm{S}_{2}: \mathrm{GA}_{3}(50 \mathrm{ppm}) ; \mathrm{S}_{3}: \mathrm{MH}(50 \mathrm{ppm})$

Over all, the seed yield and yield parameters were not much influenced due to interaction effects of nipping and hormonal spray. However, among the interactions of NxS, it was evident that in nipped plants and sprayed with hormones increased yield compared to non nipped plants without hormonal spray. Similarly, the various seed yield traits were also higher in nipped plants and sprayed with growth hormones. The investigation has indicated a relatively more beneficial influence of both nipping and hormonal spray on yield and yield attributes. The results are also in agreement with the findings of lyyannagouda (2003) in coriander and Reddy (2005) in cowpea due to nipping and hormonal spray.

\subsection{Interaction of genotypes, nipping and hormonal spray} (GXN×S)

For majority of the growth, yield and quality parameters studied, the HA-3 genotype nipped and sprayed with $\mathrm{MH}$ $\left(\mathrm{G}_{2} \mathrm{~N}_{2} \mathrm{~S}_{3}\right)$ interaction treatment combination recorded numerically higher values for most of the growth, yield and quality parameters. Within DA-8 genotype also nipped plants sprayed with $\mathrm{MH}\left(\mathrm{G}_{1} \mathrm{~N}_{2} \mathrm{~S}_{3}\right)$ outperformed other treatment combinations. However, the result of the present study has shown relatively beneficial influence of nipping and hormonal spray in both the field bean genotypes on all these parameters. Similar beneficial effects of nipping and hormonal spray are earlier reported by lyyannagouda (2003) in coriander, Sudarshan (2004) in fenugreek, Reddy (2005) in cowpea and Bulla (2009) in chickpea.

\section{Conclusion}

Between the genotypes, HA-3 genotype recorded higher growth, yield and seed quality parameters over DA-8. Nipping of plants at 55 DAS showed significantly higher growth, yield and seed quality attributes compared to no nipping. Higher seed yield and seed quality attributes were highest with $\mathrm{MH}$ sprayed plants over $\mathrm{GA}_{3}$. The interaction effects were non significant for majority of the characters studied. However, in both the genotypes nipped plants sprayed with $\mathrm{MH}$ recorded higher growth, yield and quality parameters.

\section{References}

Badge, S., Panchbhai, D.M., Ghajbhiye, R.P., 2015. Nutrient content, uptake and yield in African marigold (Tagetes 
erecta Linn.) as influenced by pinching and foliar application of gibberellic acid. Indian Journal of Agricultural Research 49(6), 534-538.

Baloch, M.S., Zubair, M., 2010. Effect of nipping on growth and yield of chickpea. Journal of Animal and Plant Sciences 20(3), 208-210.

Bulla, G., 2009. Seed technological studies in chickpea varieties (Cicer arietinum L.). Ph. D. (Agri) Thesis, University of Agricultural Sciences, Dharwad, Karnataka, India.

Cathey, H.M., 1964. Physiology of growth retarding chemicals. Annual Reviews of Plant Physiology 15, 271-302.

Chauhan, S.V.S., Singh, S.P., 1972. Effect of MH, FW-450 and Dalapon on growth, flowering and pollen viability of Capsicum annuum L. and Datura alba L. Indian Journal of Horticulture 48, 64-70.

Gujar, K.D., Srivastava, U.K., 1972. Effect of maleic hydrazide and apical pinching in okra. Indian Journal of Horticulture 26(1), 63-66.

Iyyannagouda, S., 2003. Influence of spacing, nutrition, pinching and hormones on plant growth, seed yield and quality of coriander (Coriandrum sativum L.). M.Sc. (Agri.) Thesis, University of Agricultural Sciences, Dharwad, Karnataka, India.

Key, J.L., 1969. Hormones and nucleic acid metabolism. Annual Review of Plant Physiolog 20, 419-474.

Khan, H., Latif, A., Mahmood, S., Khan, M.S.S., 2006. Effect of nipping at various stages on yield and yield components of chickpea (Cicer aeritinum L.). Journal of Research (Science), 235-240.

Krishnaveni, V., Padmalatha, T., Padma, S.S., Prasad, A.L.N., 2014. Effect of pinching and plant growth regulators on growth and flowering in fenugreek (Trigonella foenumgraecum L.). Plant Archives 14(2), 901-907.

Lakshmi, J., Gowda, R., Parashivamurthy, Narayanaswamy, S. and Shivanandan, V.N., 2015. Influence of pre-flowering pinching and Maleic hydrazide spray on plant growth, seed yield and quality attributes in fenugreek. Legume Research 38(3), 353-357.

Medina, E.O., Saavedra, A.L., 2005. El uso de regulador de crecimiento en la floricultura mexicana. Ciência y Desarrollo. Bogota 148, 1-17.

Menon, K.K.G., Srivastava, H.C., 1984. Increasing plant productivity through improved photosynthetic process. Indian Academy of Sciences (Plant Science) 23, 359-378.

Merwade, M.N., 2000. Investigations on seed production techniques and storability of chickpea (Cicer aeritinum L.). Ph.D. (Agri) Thesis, University of Agricultural Sciences, Dharwad, Karnataka, India.

Navale M.U., Aklade S.A., Desai J.R., Nannavare P.V., 2010. Influence of plant regulators on growth, flowering and yield of chrysanthemum (Dendranthema grandiflora Tzvelev) cv. IIHR-6. International Journal of Pharma and Bio Sciences 1(2).

Olfati, J.A., Malakouti, S.H., 2013. Pinching can increase faba bean yield and yield characteristics. International Journal of Vegetable Science 19, 203-206.
Reddy, P., 2005. Effect of growth retardants and nipping on growth and yield parameters in cowpea (Vigna unguiculata L.). M.Sc. (Agri.) Thesis, University of Agricultural Sciences, Dharwad, Karnataka, India.

Sajjan, A.S., Shekhargouda, M., Badanur, V. P., 2002. Influence of apical pinching and fruit picking on growth and seed yield of okra. Karnataka Journal of Agricultural Sciences 15(2), 367-372.

Sajjan, A., Jamadar, M.M., 2003. Influence of harvesting stages and drying methods on seed quality and seed mycoflora in okra seeds in northern dry zone of Karnataka. Karnataka Journal of Agricultural Sciences 16(3), 461-464.

Sarkar, R.K., Pal, P.K., 2005. Effect of crop geometry, fertility levels and nipping on physiological parameters in relation to productivity of sesame. Indian Journal of Agricultural Sciences 75(3), 143-147.

Shankargoud, I., Patil, S.A., 1994. Nipping side branches-a practical method of improving seed yield and quality of multibranched restorer lines of sunflower (Helianthus annuus L.). Seed Research 22(1), 12-14.

Sharma, A., Potdar, M.P., Pujari, B.T., Dharmaraj, P.S., 2003. Studies on response of pigeonpea to canopy modification and plant geometry. Karnataka Journal of Agriculture Research 16(1), 1-3.

Shrivastava, V. K., Sachan, S.C.P., 1971. Effect of IAA and GA on growth and yield of Okra. Indian Journal of Horticulture 28(3), 237-239.

Singh, M.S., Devi, S., 2006. Profitability of nipping in cultivation of pea (Pisum sativum) - an indigenous agro-technique in Manipur. Indian Journal of Agronomy 51(3), 206-208.

Singh, B.B., Sarkar, S.K., 1976. Effect of growth retardants on growth, flowering, productivity and chemical composition of soybeans. Haryana Journal of Horticultural Sciences 5, 195-202.

Singh, V.C., Singh, S.B., 1992, Effect of nipping on the yield of pea (Pisum sativum sub sp. Arumsis L.). Manipal Journal of Agricultural Sciences 1, 80-81.

Sudarshan, J.S., 2004. Influence of apical bud pinching, chemicals spray and physiological maturity on seed yield and quality of fenugreek (Trigonella foenum-graceum L.). M.Sc. (Agri.) Thesis, University of Agricultural Sciences, Dharwad, Karnataka, India.

Tripathi, D.K., Lalu, Chandra, B., Baghel, R.S., 2001. Effect of some growth regulators on flower drop and yield of chickpea. Journal of Food Legumes 20(1), 117-118.

Vasudevan, S.N., Sudarshan, J.S., Kurdikeri, M.B., Dharmatti, P.R., 2008. Influence of pinching of apical bud and chemical sprays on seed yield and quality of fenugreek. Karnataka Journal of Agricultural Sciences 21(1), 26-29.

Vilas, A.T., 1985. Studies on the effect of foliar spray of $\mathrm{MH}$ on seed yield, quality and seed treatment on storability in two cultivars of vegetable cowpea. M.Sc. (Agri), Thesis, University of Agricultural Sciences, Bangalore, Karnataka, India. 